\title{
Correlations between quality indices and consumer acceptance in environment-friendly 'Campbell early' grapes
}

\author{
Da Uhm Lee, Jeong Mi Bae, Kyung Hyung $\mathrm{Ku}$, Jeong Hee Choi* \\ Postharvest Technology Research Group, Korea Food Research Institute, Seongnam 13539, Korea
}

\section{친환경 포도의 품질 인자와 소비자 기호도의 상관성 분석}

\author{
이다움 · 배정미·구경형 · 최정희* \\ 한국식품연구원 저장유통연구단
}

\begin{abstract}
This study investigated the correlation between physicochemical (color, soluble solids content (SSC), pH, titratable acidity (TA), and firmness) and sensory (appearance, taste, odor, and texture) characteristics of environment-friendly 'Campbell early' grapes to identify quality indices. For analysis, samples of similar-sized grapes were collected from five orchards. The results showed that the physicochemical characteristics of $\mathrm{CIE} \mathrm{L}^{*}, \mathrm{CIE} \mathbf{a}^{*} / \mathrm{b}^{*}, \mathrm{SSC}, \mathrm{pH}$, TA, and firmness and the sensorial characteristics of color intensity, freshness of stem, odor, sourness, sweetness, and elasticity were different among groups. Correlation analysis results showed that an increase in sweetness and firmness and a decrease in sourness were associated with an increase in overall acceptance. Sourness and sweetness were positively correlated with $\mathrm{CIE} \mathrm{L}^{*}(\mathrm{r}=\mathbf{0 . 8 8})$ and firmness $(\mathrm{r}=\mathbf{0 . 9 5})$, individually. In the principal component analysis results, component $F 1$ and $F 2$ explained $44.35 \%$ and $33.77 \%$, respectively, of the total variance $(78.12 \%)$. F1 represented firmness, sweetness, elasticity, hardness, grape odor, color intensity, sweet odor, soumess, and damage degree. F2 represented CIE L*, TA, CIE a*, CIE a*/b*, SSC/TA, SSC, and peel thickness. The results showed that consumer acceptance of 'Campbell early' grapes can be determined by assessing physicochemical attributes of firmness, CIE $\mathbf{L}^{*}, \mathrm{TA}, \mathrm{CIE} \mathbf{a}^{*}, \mathrm{CIE} \mathbf{a}^{*} / \mathbf{b}^{*}$, SSC/TA, and SSC and various sensorial attributes including sweetness, fruit elasticity, fruit hardness, grape odor, and color intensity.
\end{abstract}

Key words : grape, sensory characteristic, physicochemical characteristic, principal component analysis, quality indices

\section{서 론}

포도는 우리나라의 여름철 주요 과실 중 하나로 한국농 촌경제연구소의 발표에 따르면 2015년 국내 포도 재배면적 은 $15,397 \mathrm{ha}$ 이며, 생산량은 271,000 톤으로 주요 재배 품종 은 Campbell early, Kyoho, Muscat Bailey A(MBA) 등 생과 용이 많다고 보고하였다(1). 그 중 Campbell early가 67.4\% 로 가장 넓은 면적을 차지하고 있는데 FTA(free trade

*Corresponding author. E-mail : choijh@kfri.re.kr Phone : 82-31-780-9156, Fax : 82-31-780-9254

Received 26 October 2016; Revised 22 November 2016; Accepted 29 November 2016.

Copyright (c) The Korean Society of Food Preservation. All rights reserved. agreement) 등 농산물의 수입개방이 확대되면서 수입포도 증가로 인한 수익성 저하로 재배 면적이 감소하고 있는 실정이다. 이에 포도 산업의 경쟁력 강화를 위하여 고품질 포도 생산, 품질 객관화, 유통 환경 개선 등 다양한 노력이 수행되고 있다(2). 농산물표준규격에 따르면 포도의 품질 등급은 포도송이의 무게가 $300 ~ 450 \mathrm{~g}$ 이고 낱알 간 숙도와 크기가 고르며, 과분의 부착이 양호한 것을 ‘특' 등급으로 분류한다. 농촌진흥청은 'Campbell early'의 숙도를 기준으 로 품질을 예측할 수 있는 칼라차트를 제공하고 있으며, 포도의 착립부터 적숙까지를 시기별로 총 10 단계로 분류하 여 사진, 당도 그리고 산도를 제시하고 있다(3). 칼라차트에 서 제시하는 최상의 품질은 마지막 10 단계로서 포도 고유 의 색이 짙고 당도가 $15.9{ }^{\circ} \mathrm{Brix}$ 이상이며, 산도가 $0.51 \sim 0.60 \%$ 로 정의하고 있다. 그러나 이화학적 특성만으로 
정의 된 품질 등급 기준은 일부 품질 특성에 대한 주관적인 견해에 의해 독립적으로 평가되는 한계를 가진다(4). Pages 와 Tenenhaus(5)는 이화학적 특성 분석을 병행한 관능적 특성 분석은 발생할 수 있는 특성 오류를 보완할 수 있다고 하였다. 또한 Kim 등(6)은 현재 농산물 시장이 소비자 위주 의 시장으로 변화하고 있기 때문에 소비자 기호도에 기반한 고품질 상품의 생산 및 출하가 농산물의 국내외 경쟁력을 높이는 수단이 될 것이라고 하였다. 이에 최근 토마토, 사과 그리고 귤 등 과일의 품질 평가를 위하여 소비자 기호도에 기반한 다양한 품질 등급 기준이 연구되고 있다(7-9). 포도 의 품질 평가를 위한 선행 연구로는 Cho 등(10)은 'Campbell early' 포도의 저장 중 품질변화를 추적하고 이화학적 성분 및 관능지표 평가를 통해 전체적인 기호도가 조직감, 신맛 을 포함한 단맛 그리고 soluble solid content(SSC)와 높은 상관성을 보인다고 보고한 바 있다. 또한, Parpinello 등(11) 은 NIR을 사용하여 table grape의 과피 색을 측정하여 SSC 와 소비자 기호도를 예측할 수 있다고 하였으며, Segade 등(12)은 'Red globe'와 'Crimson seeless' 포도의 숙도에 따른 경도 측정을 통하여 $\mathrm{SSC}$ 와 소비자 기호도가 높은 수 확시기를 예측할 수 있다고 하였다.

본 연구에서는 친환경 방법으로 재배 된 'Campbell early' 포도를 대상으로 과피의 색, SSC, pH, titratable acidity(TA) 그리고 경도 등 이화학적 품질 특성과 외관, 맛, 향 그리고 조직감 등 관능적 품질 특성을 각각 조사한 후 상관관계를 분석하여 수확된 포도의 품질예측을 위한 품질지표를 구명 하고자 수행되었다.

\section{재료 및 방법}

\section{실험재료}

포도 시료는 경상북도 상주에 위치한 5농가에서 동일한 친환경 방법으로 하우스에서 재배된 'Campbell early' 품종 으로 2014년 9월에 수확하여 상처가 없고 크기가 균일한 것을 선별 후 $5^{\circ} \mathrm{C}$ 저장고에 보관하며 조사 및 분석에 사용하 였다.

\section{이화학적 품질 특성}

이화학적 품질 특성 분석을 위하여 포도송이를 줄기 부 위, 중간 부위, 그리고 아래 부위 등 세 부위로 나누어 각 부위에서 포도 과립 4 개씩 사용하였으며, 각 농가마다 5 반 복 진행하였다, 포도 과피의 색도는 과분을 닦아낸 후 색차 계(Spectrometer CM-700d, Konica Minolta Optics INC., Osaka, Japan)로 측정하여 $\mathrm{CIE} \mathrm{L}^{*}, \mathrm{a}^{*}$ 그리고 $\mathrm{b}^{*}$ 값으로 나타 냈다. 포도의 $\mathrm{SSC}, \mathrm{pH}$, 그리고 $\mathrm{TA}$ 는 포도 과피와 과육을 함께 마늘 압착기로 착즙 후 착즙액을 거즈로 여과한 여과 액을 사용하여 측정하였다. $\mathrm{SSC}$ 는 당도계(N-1E, Atago Co.,
Std., Tokyo, Japan)로 측정 후 ${ }^{\circ} \mathrm{Brix}$ 로 나타냈고, $\mathrm{pH}$ 는 $\mathrm{pH}$ meter(Orion 720, Orion Research Inc., Beverly, MA, USA)를 사용하여 측정하였다. $\mathrm{TA}$ 는 여과액 $3 \mathrm{~mL}$ 와 증류수 $27 \mathrm{~mL}$ 를 혼합하여 교반하면서 $\mathrm{pH} 8.2$ 가 될 때까지 $0.01 \mathrm{~N} \mathrm{NaOH}$ 용액으로 적정한 뒤 tartaric acid를 기준으로 환산하여 \%로 나타냈다. 포도 과육의 경도는 포도 과립을 줄기에서 분리 후 과피을 제거하지 않은 상태로 texture analyser(Stable Micro Systems, Godalming, Surrey, UK)를 이용하여 texture profile analysis(TPA) 방법으로 측정하였다. 측정에 사용한 probe는 직경 $25 \mathrm{~mm}$ 의 원통형 probe이고, 측정 조건은 strain은 $20 \%$ 그리고 test speed는 $0.8 \mathrm{~mm} / \mathrm{s}$ 이다.

\section{관능적 품질 특성}

관능적 품질 특성 분석은 20 50대 직장인 95명을 대상으 로 실시하였고, 남자와 여자의 비율은 각각 $55.8 \%$ 그리고 $44.2 \%$ 였다. 포도의 관능검사는 소비자가 포도 결정 시 중요 하게 생각하는 외관, 향, 맛 그리고 조직감으로 나누어 총 4 개 특성에 대한 강도를 9점 선척도로 평가 후 각 특성에 대한 종합적 선호도를 결정하는 방식으로 진행하였으며, 마지막으로 전반적인 기호도를 평가하도록 하였다. 외관 특성의 세부 평가 항목은 색의 정도, 과피의 손상도, 줄기의 신선도 그리고 과피의 두께이고, 향 특성의 세부 평가 항목 은 신 향, 단 향, 포도 향 그리고 이취이다. 맛 특성은 포도 중간 부위를 섭취 후 평가하도록 하였고, 세부 평가 항목은 신맛과 단맛이며, 조직감의 세부 평가 항목은 과립의 탄력 도, 경도 그리고 다즙성이다. 과립의 탄력도는 엄지와 검지 로 포도 과립이 터지지 않을 정도로 눌러봤을 때의 힘을 평가하였으며, 경도는 포도 과립을 입에 넣고 씹었을 때의 힘을 평가하였다.

\section{통계 분석}

친환경 포도의 농가에 따른 이화학적 및 관능적 품질 차이를 파악하기 위하여, SPSS 통계분석 프로그램(Version 17, SPSS Inc., Chicago, IL, USA)을 이용하여 one-way ANOVA 중 Duncan을 통해 각 시료간의 유의적 차이를 검정하였다( $<<0.05)$. 또한 각 시료의 이화학적 품질 특성과 관능적 품질 특성간의 관계를 요약하여 나타내기 위해 요인 간의 상관분석(pearson's correlation analysis)과 주성분 분 석(principle component analysis)을 실시하였다.

\section{결과 및 고찰}

\section{이화학적 품질 특성}

포도의 소비자 기호도와 관련된 품질 지표를 도출하기 위하여 이화학적 품질 특성을 분석하였으며 결과는 Table 1 과 같다. 각 농가에서 수확된 포도송이의 무게를 측정한 
결과 $\mathrm{A}$ 농가는 $368.52 \mathrm{~g}$ 으로 유의적으로 가장 컸고, $\mathrm{C}$ 농가 는 $344.02 \mathrm{~g}$ 이였으며 $\mathrm{B}$ 농가, $\mathrm{D}$ 농가, 그리고 $\mathrm{E}$ 농가는 280 $\mathrm{g}$ 이하로 나타났다. 농산물표준규격에 따르면 'Campbell early'는 포도송이의 무게가 300 450 g 일 때 '특' 등급으로 분류하고 있으며, $350 \mathrm{~g}$ 이상은 '상' 등급 그리고 $300 \mathrm{~g}$ 이하는 '하' 등급으로 분류된다. 포도의 과피 색 측정 결과 $\mathrm{CIE} \mathrm{L}^{*}$ 값의 경우 $\mathrm{B}$ 농가, $\mathrm{C}$ 농가, 그리고 $\mathrm{D}$ 농가는 24.19 24.31로 유의적 차이가 없었고 $\mathrm{A}$ 와 $\mathrm{E}$ 농가가 각각 24.72 와 24.50으로 상대적으로 높은 값을 나타냈다. $\mathrm{CIE}$ $\mathrm{a}$ *값은 $\mathrm{A}$ 농가가 높고 $\mathrm{D}$ 농가가 낮았으며, $\mathrm{CIE} \mathrm{b}^{*}$ 값은 $\mathrm{D}$ 농

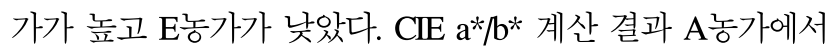
-0.70 으로 유의적으로 가장 낮은 값을 나타냈으며 $\mathrm{C}$ 농가, $\mathrm{D}$ 농가, 그리고 $\mathrm{E}$ 농가는 $-0.45 \sim-0.37$ 로 $\mathrm{A}$ 농가에 비하여 유 의적으로 높은 값을 나타냈다. Park 등(13)은 'Campbell early’의 과피 색은 변색기 이후 자흑색이 강해지면서 Hunter L과 b값이 꾸준히 감소하여 수확기에는 가장 낮은 값을 나타내고, Hunter a값은 변색기 이후 꾸준히 증가한다 고 보고하였다. 또한 Carreno 등(14)은 red table grape를 대상으로 색차계를 이용한 착색지수를 활용하여 포도를 선별할 수 있다고 하였고, Hwang 등(2)은 포도를 적숙기 이전에 수확하는 것은 착색 불량 등 품질 저하의 주요 요인 이라고 하였다. 실험 결과 포도의 과피 색은 소비자의 기호 도를 반영하는 품질 지표로 활용될 가능성이 높은 것으로 판단된다.
포도의 SSC는 A농가를 제외한 4개 농가에서 14.96 $15.34{ }^{\circ} \mathrm{Brix}$ 로 유의적 차이를 나타내지 않았고, $\mathrm{A}$ 농가는 $13.46{ }^{\circ} \mathrm{Brix}$ 로 유의적으로 낮은 값을 나타냈다. 농산물표준 규격에 따르면 'Campbell early'의 SSC는 $14{ }^{\circ} \mathrm{Brix}$ 이상일 경우 ‘특' 등급 그리고 $12 \sim 14{ }^{\circ} \mathrm{Brix}$ 는 '상' 등급으로 분류된 다. 포도의 $\mathrm{pH}$ 는 모든 농가에서 $\mathrm{pH}$ 3.54 3.69로 유의적 차이가 크지 않았으나, $\mathrm{TA}$ 측정치는 $\mathrm{A}$ 농가가 $0.74 \%$ 로 다 른 농가에 비해 유의적으로 높았고, 그 외 농가는 0.61 $0.66 \%$ 로 유의적 차이가 없었다. 당도와 산도는 포도의 숙도 와 관련이 있는 특성으로 숙도가 높아질수록 당도는 증가하 고 산도는 감소하는 것으로 알려져 있다(15). 이러한 포도의 특성을 이용하여 ${ }^{\circ} \mathrm{Brix} \times \mathrm{pH}$ 값이나, ${ }^{\circ} \mathrm{Brix} / \mathrm{TA}$ 를 적정 성숙 시기를 판단하는 척도로 사용하기도 한다 $(16,17)$. 이에 본 연구에서 농가에 따른 'Campbell early'의 SSC $\left({ }^{\circ} \mathrm{Brix}\right) / \mathrm{TA}$ 환산 결과 $\mathrm{A}$ 농가가 18.65 로 유의적으로 가장 낮았으며, B E농가는 22.81 25.23으로 유의적 차이가 없었다. Bisson (14)은 와인용 포도의 경우 ${ }^{\circ} \mathrm{Brix} / \mathrm{TA}$ 가 30 32일 때 적숙기 이며 37 38은 과숙기라고 보고하였다. 그러나 'Campbell early'의 경우 와인에 주로 사용되는 포도에 비해 당도가 낮고, 가공용이 아닌 생과용이므로 'Campbell early'의 특성 에 맞는 SSCTTA를 활용한 지표 개발이 필요하다. 포도 과립 의 경도 측정 결과 $\mathrm{C}$ 농가에서 $593.20 \mathrm{gf}$ 로 유의적으로 가장 높게 측정되었고, $\mathrm{A}$ 농가에서 $481.17 \mathrm{gf}$ 로 가장 낮게 측정되 어 농가에 따라 다른 특성을 보였다.

Table 1. Physiochemical characteristics of 'Campbell early' grapes cultivated in various orchards

\begin{tabular}{|c|c|c|c|c|c|c|c|c|c|c|}
\hline \multirow{2}{*}{ Orchard } & \multicolumn{10}{|c|}{ Physiochemical characteristics } \\
\hline & Weight $(\mathrm{g})$ & $\mathrm{CIE} \mathrm{L}^{*}$ & $\mathrm{CIE} \mathrm{a}^{*}$ & $\mathrm{CIE} \mathrm{b}^{*}$ & $\operatorname{CIE~} a^{*} / b^{*}$ & SSC $\left({ }^{\circ}\right.$ Brix $)$ & $\mathrm{pH}$ & TA $(\%)$ & SSC/TA & Firmness (gf) \\
\hline $\mathrm{A}$ & $368.52^{\text {al) }}$ & $24.72^{\mathrm{a}}$ & $0.40^{\mathrm{a}}$ & $-0.58^{\mathrm{ab}}$ & $-0.70^{b}$ & $13.46^{\mathrm{b}}$ & $3.63^{\mathrm{ab}}$ & $0.74^{\mathrm{a}}$ & $18.65^{\mathrm{b}}$ & $481.17^{\mathrm{b}}$ \\
\hline B & $271.06^{c}$ & $24.31^{\mathrm{bc}}$ & $0.31^{\mathrm{ab}}$ & $-0.59^{\mathrm{ab}}$ & $-0.53^{\mathrm{ab}}$ & $14.96^{\mathrm{a}}$ & $3.54^{\mathrm{b}}$ & $0.66^{\mathrm{b}}$ & $22.81^{\mathrm{a}}$ & $494.72^{b}$ \\
\hline $\mathrm{C}$ & $344.02^{b}$ & $24.36^{\mathrm{bc}}$ & $0.29^{a b}$ & $-0.63^{\mathrm{ab}}$ & $-0.45^{\mathrm{a}}$ & $15.38^{\mathrm{a}}$ & $3.64^{\mathrm{ab}}$ & $0.63^{b}$ & $24.26^{\mathrm{a}}$ & $593.20^{\mathrm{a}}$ \\
\hline $\mathrm{D}$ & $261.82^{\text {cd }}$ & $24.19^{c}$ & $0.20^{b}$ & $-0.55^{\mathrm{a}}$ & $-0.37^{\mathrm{a}}$ & $15.00^{\mathrm{a}}$ & $3.60^{\mathrm{ab}}$ & $0.64^{b}$ & $23.56^{\mathrm{a}}$ & $539.45^{\mathrm{ab}}$ \\
\hline $\mathrm{E}$ & $243.86^{d}$ & $24.50^{\mathrm{ab}}$ & $0.28^{\mathrm{ab}}$ & $-0.67^{b}$ & $-0.40^{\mathrm{a}}$ & $15.34^{\mathrm{a}}$ & $3.69^{\mathrm{a}}$ & $0.61^{\mathrm{b}}$ & $25.23^{\mathrm{a}}$ & $484.54^{b}$ \\
\hline
\end{tabular}

${ }^{1)}$ Means ( $\mathrm{n}=5$ ) with different superscripts within the same column are significantly different by Duncan's multiple range test at $\mathrm{p}<0.05$.

Table 2. Sensory characteristics of 'Campbell early' grapes cultivated in various orchards

\begin{tabular}{|c|c|c|c|c|c|c|c|c|c|c|c|c|c|c|c|c|c|c|}
\hline \multirow[b]{2}{*}{ Orchard } & \multicolumn{5}{|c|}{ Appearance } & \multicolumn{5}{|c|}{ Odor } & \multicolumn{3}{|c|}{ Taste } & \multicolumn{4}{|c|}{ Texture } & \multirow{2}{*}{$\begin{array}{l}\text { Overall } \\
\text { acceptance }\end{array}$} \\
\hline & $\begin{array}{c}\text { Color } \\
\text { intensity }\end{array}$ & $\begin{array}{c}\text { Damage } \\
\text { degree }\end{array}$ & $\begin{array}{l}\text { Freshness } \\
\text { of stem }\end{array}$ & $\begin{array}{c}\text { Peel } \\
\text { thickness }\end{array}$ & Preference & $\begin{array}{l}\text { Sour } \\
\text { odor }\end{array}$ & $\begin{array}{c}\text { Sweet } \\
\text { odor }\end{array}$ & $\begin{array}{c}\text { Grape } \\
\text { odor }\end{array}$ & $\begin{array}{l}\text { Off } \\
\text { odor }\end{array}$ & Preference & $\begin{array}{l}\text { Sour } \\
\text { ness }\end{array}$ & Sweetness & Preference & Elasticity & Hardness & Juiciness & Preference & \\
\hline A & $7.31^{\mathrm{bcl})}$ & $2.31^{\mathrm{a}}$ & $7.24^{\mathrm{ab}}$ & $6.15^{\mathrm{a}}$ & $7.21^{\mathrm{bc}}$ & $3.65^{\mathrm{a}}$ & $5.84^{\mathrm{a}}$ & $5.68^{\mathrm{ab}}$ & $3.68^{\mathrm{a}}$ & $6.99^{\mathrm{ab}}$ & $4.91^{\mathrm{a}}$ & $6.12^{\mathrm{bc}}$ & $6.19^{b c}$ & $7.00^{b}$ & $6.18^{\mathrm{a}}$ & $6.54^{\mathrm{a}}$ & $6.66^{b}$ & $6.62^{b c}$ \\
\hline B & $7.45^{b}$ & $2.35^{\mathrm{a}}$ & $7.62^{\mathrm{a}}$ & $5.93^{\mathrm{a}}$ & $7.73^{\mathrm{a}}$ & $3.69^{\mathrm{a}}$ & $5.87^{\mathrm{a}}$ & $6.30^{\mathrm{a}}$ & $3.56^{\mathrm{a}}$ & $7.48^{\mathrm{a}}$ & $4.31^{\mathrm{ab}}$ & $6.28^{\mathrm{bc}}$ & $6.99^{a}$ & $7.01^{b}$ & $6.28^{\mathrm{a}}$ & $6.62^{\mathrm{a}}$ & $6.80^{b}$ & $7.01^{\mathrm{ab}}$ \\
\hline $\mathrm{C}$ & $7.63^{\mathrm{ab}}$ & $2.28^{\mathrm{a}}$ & $7.33^{\mathrm{a}}$ & $6.11^{\mathrm{a}}$ & $7.48^{\mathrm{ab}}$ & $3.49^{\mathrm{a}}$ & $5.87^{\mathrm{a}}$ & $6.25^{\mathrm{a}}$ & $3.63^{\mathrm{a}}$ & $7.29^{\mathrm{ab}}$ & $3.92^{b}$ & $7.00^{\mathrm{a}}$ & $6.96^{\mathrm{a}}$ & $7.56^{\mathrm{a}}$ & $6.31^{\mathrm{a}}$ & $6.48^{\mathrm{a}}$ & $7.24^{a}$ & $7.35^{\mathrm{a}}$ \\
\hline D & $7.88^{\mathrm{a}}$ & $2.50^{\mathrm{a}}$ & $6.88^{b}$ & $6.07^{\mathrm{a}}$ & $6.97^{\mathrm{c}}$ & $3.58^{\mathrm{a}}$ & $5.61^{\mathrm{a}}$ & $6.26^{\mathrm{a}}$ & $3.76^{\mathrm{a}}$ & $6.96^{b}$ & $3.88^{\mathrm{b}}$ & $6.68^{\mathrm{ab}}$ & $6.56^{\mathrm{ab}}$ & $7.33^{a b}$ & $6.14^{\mathrm{a}}$ & $6.61^{\mathrm{a}}$ & $7.04^{\text {ab }}$ & $7.11^{\mathrm{a}}$ \\
\hline E & $6.90^{\circ}$ & $2.52^{\mathrm{a}}$ & $7.36^{a}$ & $5.86^{\mathrm{a}}$ & $7.05^{\mathrm{bc}}$ & $3.44^{\mathrm{a}}$ & $5.30^{\mathrm{a}}$ & $5.51^{b}$ & $3.29^{\mathrm{a}}$ & $6.07^{\mathrm{c}}$ & $4.79^{\mathrm{a}}$ & $5.88^{\mathrm{c}}$ & $5.89^{\mathrm{c}}$ & $5.95^{\mathrm{c}}$ & $5.59^{\mathrm{a}}$ & $6.30^{\mathrm{a}}$ & $5.95^{c}$ & $6.36^{\circ}$ \\
\hline
\end{tabular}

${ }^{1)}$ Means ( $\mathrm{n}=95$ ) with different superscripts within the same column are significant different by Duncan's multiple range test at $\mathrm{p}<0.05$. 


\section{관능적 품질 특성}

포도의 관능적 품질 특성 분석은 외관, 향, 맛 그리고 조직감의 강도와 선호도를 9단계로 평가 후 전반적인 기호 도를 9점 선척도로 측정하였으며, 결과는 Table 2에 나타냈 다. 포도의 과피 색은 $\mathrm{D}$ 농가가 7.88 로 포도 고유의 색이 가장 짙다고 평가되었고 $\mathrm{E}$ 농가가 6.90 으로 유의적으로 가 장 낮게 평가되었다. 포도의 과피 손상 정도는 모든 농가에 서 2.28 2.52로 유의적 차이가 없었으며 매우 낮게 평가되 어 모든 농가에서 과피의 손상이 거의 없는 것으로 나타났 다. 줄기의 신선도는 $\mathrm{D}$ 농가가 6.88 로 유의적으로 가장 낮게 측정되었고, 나머지 농가는 7.24 7.62로 유의적 차이가 크 지 않았다. 포도 과립의 과피 두께는 모든 농가에서 5.86 6.11로 농가에 따른 차이가 없는 것으로 나타났다. 외관에 대한 종합적인 선호도를 평가한 결과는 줄기의 신선 도와 유사하게 평가되어 B농가가 7.73으로 가장 높았고 $\mathrm{D}$ 농가가 6.97로 가장 낮았다. 외관 평가 결과 과피의 색과 줄기의 신선도에서 농가에 따른 차이를 보였으며, 특히 줄 기의 신선도는 외관의 종합적 선호도에 많은 영향을 미치는 것으로 나타났다.

포도의 향 특성 평가를 위하여 신 향, 단 향, 포도 고유의 향 그리고 이취의 강도 평가 후 향에 대한 종합적 선호도를 평가했다. 평가 결과 신 향, 단 향 그리고 이취는 농가에 따른 유의적 차이가 없는 것으로 나타났다. 반면 포도 고유 의 향 평가 결과 다른 농가에 비해 $\mathrm{E}$ 농가에서 5.51로 낮게 평가됐다. 또한 향에 대한 종합적 선호도는 포도 고유의 향이 가장 낮게 나타난 $\mathrm{E}$ 농가가 6.07 로 가장 낮게 나타났다. 본 평가 결과 포도의 신 향과 단 향은 선호도에 미치는 영향이 없으며, 포도 고유의 향은 품질 평가 항목으로 이용 가능할 것으로 생각된다. 'Campbell early'의 향 성분은 에스 터류(47.08\%), C6-화합물(31.35\%) 그리고 알코올류 $(8.01 \%)$ 가 대부분을 차지하고 있고, 그 중 ethyl acetate가 주요 향기 성분으로 알려져 있다(18).

포도의 신맛은 $\mathrm{A}$ 농가와 $\mathrm{E}$ 농가에서 각각 4.91 과 4.79로 다른 농가에 비해 유의적으로 신맛이 강한 것으로 평가됐 고, $\mathrm{C}$ 농가와 $\mathrm{D}$ 농가는 4점 이하로 다른 농가에 비하여 신맛 이 약한 것으로 나타났다. 단맛의 강도는 $\mathrm{C}$ 농가에서 7.00 으 로 유의적으로 가장 높게 평가됐고 $\mathrm{E}$ 농가는 5.88 로 가장 낮게 평가됐다. 맛의 종합적 선호도는 신맛이 상대적으로 약한고 단맛이 강한 $\mathrm{B}$ 농가와 $\mathrm{C}$ 농가에서 6.50 이상으로 유 의적으로 높게 나타났고 신맛이 강하고 단맛이 약했던 $\mathrm{E}$ 농 가는 5.89 로 가장 낮게 평가됐다. 따라서 포도의 관능적인 신맛과 단맛 특성은 맛 기호도를 결정하는 주요 인자임이 확인되었다.

포도 과립의 탄력도와 경도 그리고 다즙성의 강도를 측 정 후 조직감의 종합적 선호도를 평가하였다. 과육의 경도 는 모든 농가에서 5.59 6.31로 유의적 차이가 없었으며, 다즙성도 6.30 6.62로 농가에 따른 차이가 없는 것으로 나
타났다. 반면 탄력도는 $\mathrm{C}$ 농가가 7.56으로 유의적으로 가장 높게 나타났고 $\mathrm{E}$ 농가가 5.95 로 낮게 나타나 농가에 따라 확연한 차이를 보였다. 조직감의 종합적 선호도는 탄력도 가 가장 높게 측정 된 $\mathrm{C}$ 농가가 7.24 로 유의적으로 높은 선호도를 나타냈고, 탄력도가 가장 낮게 측정된 $\mathrm{E}$ 농가가 5.95로 유의적으로 낮게 평가됐다. Cho 등(10)은 'Campbell early'의 저장조건에 따른 기호도 평가 결과 저장에 따른 포도의 조직감 변화가 기호도에 크게 영향을 주며, 조직감 이 높을수록 기호도가 높게 나왔다고 보고하였다.

포도의 전반적인 기호도는 외관, 향, 맛 그리고 조직감의 선호도가 높았던 $\mathrm{C}$ 농가가 7.35 로 가장 높게 나타났고, 이와 반대로 모든 선호도 항목에서 가장 낮은 점수를 받았던 $\mathrm{E}$ 농가가 6.36으로 가장 낮은 점수를 보였다. 본 결과를 통해 외관의 선호도에 영향을 준 과피 색과 줄기의 신선도, 향의 선호도에 영향을 준 포도 고유의 향, 맛의 선호도에 영향을 준 신맛과 단맛 그리고 조직감 선호도에 영향을 준 과립의 탄력도가 소비자 기호도 평가에 활용 가능성이 높을 것으로 판단되었다.

\section{이화학적 품질 특성과 관능적 품질 특성의 상관분석}

포도의 이화학적 품질 특성과 관능적 품질 특성의 상관 분석 결과는 Table 3 에 나타냈다. 이화학적 품질 특성 중 과피의 $\mathrm{CIE} \mathrm{L}^{\star}$ 값은 $5 \%$ 유의 수준에서 $\mathrm{TA}$ 와 0.89 의 높은 정의 상관성을 보였고, 관능적 품질 특성인 신맛과 0.88 의 높은 정의 상관성을 보여 포도의 과피 색이 밝을수록 산미 가 높은 것으로 나타났다. 과피의 $\mathrm{CIE} \mathrm{a}^{*}$ 와 $\mathrm{b}^{*}$ 는 단독으로 는 다른 이화학적 특성과 유의적 상관도를 보이지 않았으 나, $\mathrm{CIE} \mathrm{a}^{*} / \mathrm{b}^{*}$ 는 $\mathrm{SSC}$ 및 $\mathrm{SSC} / \mathrm{TA}$ 와 각각 $0.89^{*}$ 와 $0.92 *$ 의 높은 상관성을 보여 과피의 $\mathrm{CIE} \mathrm{a}^{\star} / \mathrm{b}^{\star}$ 측정을 통하여 $\mathrm{SSC}$ 및 $\mathrm{SSC} / \mathrm{TA}$ 를 예측 가능할 것으로 보인다.

포도의 당도를 나타내는 SSC는 TA와 $1 \%$ 유의 수준에서 -0.91 의 높은 부의 상관성을 보였고 이와 마찬가지로 관능 적 품질 특성인 단맛과 신맛은 $-0.90^{*}$ 의 부의 상관성을 보여 당도가 높아질수록 산도가 감소하는 것으로 나타났다. 또 한 포도의 관능적 품질 특성인 단맛은 이화학적 품질 특성 중 포도 과립의 경도와 $5 \%$ 유의 수준에서 0.95 의 높은 정의 상관성을 보여 과립의 경도 측정을 통하여 단맛의 강도를 예측할 수 있을 것으로 판단된다. 특히 포도의 단맛은 관능 적 품질 특성 중 과립의 탄력도와 $0.88^{*}$ 의 높은 정의 상관성 을 보였는데 이러한 결과를 통하여 포도의 경도와 단맛이 상관성이 높다는 것을 알 수 있다. Moigne 등(19)과 Maury 등(20)은 포도의 관능적 특성은 경도와 높은 상관성을 보인 다고 보고하여 본 실험과 유사한 결과를 보였다. 포도의 맛 선호도는 신맛과 부의 상관성을 보였고, 단맛과 정의 상관성을 보였으나 두 항목 모두 유의적이지는 않았다. 반 면 관능적 품질 특성 중 포도 고유의 향은 맛 선호도와 $0.93^{*}$ 의 높은 정의 상관성을 보여, 포도의 풍미가 맛 평가에 


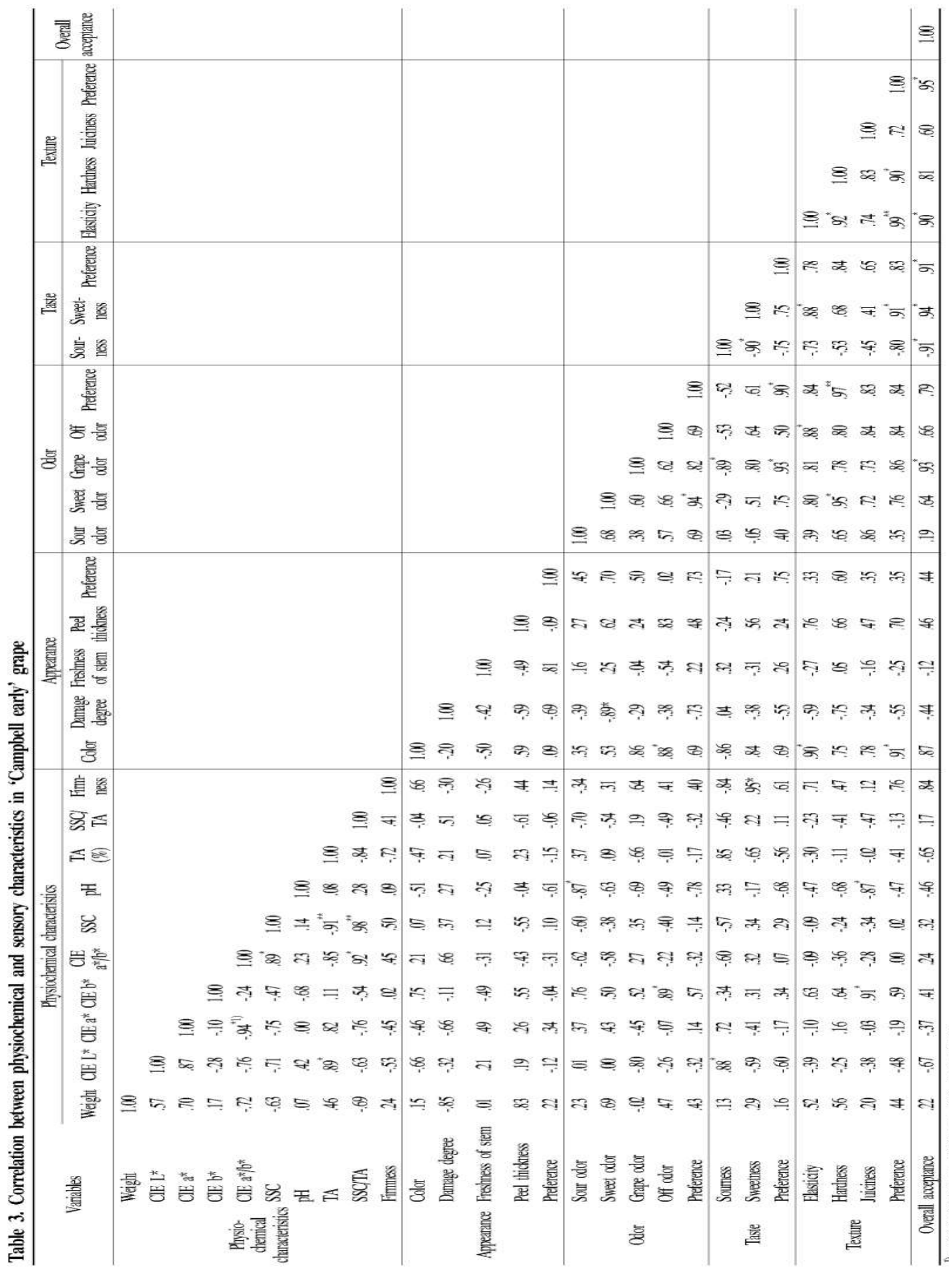


많은 영향을 주는 것으로 생각된다. 포도의 전반적인 기호 도 평가는 포도 고유의 향, 단맛 그리고 과립의 탄력도와 $5 \%$ 유의 수준에서 0.90 이상의 높은 정의 상관성을 보였고, 신맛과 $-0.91^{*}$ 의 부의 상관성을 보였다. 이러한 결과를 통해 포도는 포도 고유의 향과 단맛이 강하며 신맛이 약하고 조직감이 단단할수록 소비자 기호도가 높다는 것을 알 수 있다.

\section{주성분 분석}

포도의 품질지표로 활용 가능할 것으로 보이는 이화학적 품질 특성과 관능적 품질 특성, 그리고 전반적인 기호도의 주성분 분석을 실시한 결과 고유치 3 이상인 주성분은 2 개 로서 제 1주성분(F1)은 $44.35 \%$ 그리고 제 2주성분(F2)는 $33.77 \%$ 의 설명력을 갖으며 총 설명력은 $78.12 \%$ 였다(Fig. 1). 제 1 주성분 중 이화학적 품질 특성은 경도로 나타났고 관능적 품질 특성은 단맛, 과립의 탄력도, 경도, 포도 고유의 향, 과피 색, 단 향, 신맛 그리고 과피의 손상도로 거의 모든 항목이 관능적 품질 특성인 것으로 나타났다. 제 2 주성분 중 이화학적 품질 특성은 $\mathrm{CIE} \mathrm{a}^{\star} / \mathrm{b}^{*}, \mathrm{SSC} / \mathrm{TA}, \mathrm{SSC}$, 포도송 이의 무게, $\mathrm{CIE} \mathrm{a}$, $\mathrm{TA}$ 그리고 $\mathrm{CIE} \mathrm{L}^{*}$ 나타났고 관능적 품질 특성은 과피의 손상도와 과피의 두께로 제 2 주성분의 대부분은 이화학적 품질 특성인 것으로 나타났다.

제 1 주성분과 제 2 주성분을 직교변수로 사용하여 각 측 정 항목간의 상관성과 각 측정 항목과 시료와의 관계를 Fig. 1에 나타냈다. Fig. 1은 제 1주성분을 기준으로 좌우로 구분되어지는 것을 관찰할 수 있는데 각각의 품질 특성과 시료군의 공간적인 분포가 어떠한 관계가 있는지 알아보기 위하여 각 시료군의 품질지표 분석 결과(Table 1,2$)$ 와 비교 하였다. PCA score plot의 우측에는 단맛, 조직감, 포도 향 그리고 과피 색 등과 관련된 항목이 위치해 있으며 시료군 은 $\mathrm{SSC}, \mathrm{SSC} / \mathrm{TA}$ 그리고 $\mathrm{CIE} \mathrm{a}^{\star} / \mathrm{b}^{\star}$ 값이 높고 조직감이 단단 하며 과피 색과 포도 향이 진한 $\mathrm{C}$ 농가와 $\mathrm{D}$ 농가가 분포해

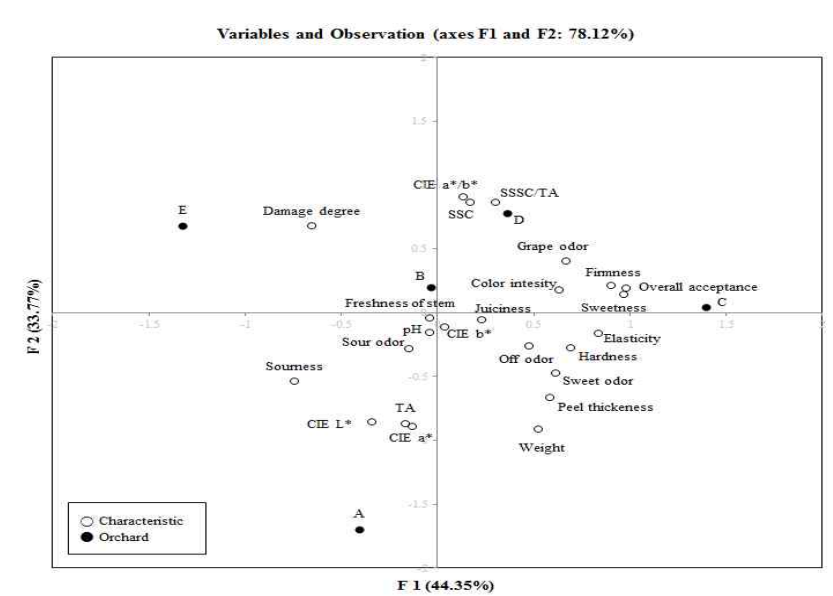

Fig. 1. Principal component analysis (PCA) between physiochemical and sensory characteristics of 'Campbell early' grapes.
있다. 반대로 PCA score plot의 좌측에는 신맛, $\mathrm{CIE} \mathrm{L}^{*}$ 등과 관련된 항목이 위치해 있고, 시료군은 $\mathrm{CIE} \mathrm{L}^{*}$ 값과 $\mathrm{TA}$ 가 높고 $\mathrm{pH}$ 가 낮은 $\mathrm{A}$ 농가와 $\mathrm{E}$ 농가가 분포해있으며, 이들 시료 군의 경우 전반적인 기호도가 각각 6.62 그리고 6.36 으로 다른 시료군에 비하여 낮은 특징을 가진다. 이러한 결과들 을 통해 PCA score plot의 시료와 품질 항목간의 공간적인 분포위치가 밀접한 상관관계가 있음을 알 수 있다.

\section{요 약}

본 연구는 'Campbell early' 포도의 품질예측을 위한 품질 지표를 구명하기 위하여 과피 색, $\mathrm{SSC}, \mathrm{pH}, \mathrm{TA}$ 그리고 경도 등 이화학적 품질 특성과 외관, 맛, 향 그리고 조직감 등 관능적 품질 특성을 각각 조사한 후 상관관계를 분석하였 다. 동일한 크기의 포도를 5 군데 농장으로부터 수집하여 본 연구에 시료로 사용하였다. 이화학적 품질 특성 분석 결과 과피의 $\mathrm{CIE} \mathrm{L}^{*}, \mathrm{CEE} \mathrm{a}^{*} / b^{*}, \mathrm{SSC}, \mathrm{pH}, \mathrm{TA}$ 그리고 경도가 시료군 간의 차이를 보였고, 관능적 품질 특성 분석 결과 과피 색의 강도, 줄기의 신선도, 포도 고유의 향, 신맛, 단맛 그리고 과립의 탄력도가 시료군 간의 차이를 보였다. 상관 성 분석 결과 전반적인 기호도는 신맛이 약하고 단맛이 강하며, 경도가 단단할수록 높은 것으로 나타났다. 신맛은 이화학적 품질 특성 중 $\mathrm{CIE} \mathrm{L}$ *값과 $0.88^{*}$ 의 상관성을 보이 고, 단맛의 경우 이화학적 품질 특성 중 경도와 $0.95^{\star}$ 의 상관성을 보였다. 포도의 이화학적 품질 특성과 관능적 품 질 특성의 주성분 분석을 실시한 결과 제 1 주성분은 $44.35 \%$ 그리고 제 2 주성분은 $33.77 \%$ 의 설명력을 갖으며 총 설명력 은 $78.12 \%$ 였다. 제 1 주성분 중 이화학적 품질 특성은 경도 로 나타났고 관능적 품질 특성은 단맛, 과립의 탄력도 과육 의 경도, 포도 향, 색의 정도, 단 향, 신맛 그리고 과피의 손상도로 나타났다. 제 2주성분 중 이화학적 품질 특성은 $\mathrm{CIE} \mathrm{L*} \mathrm{TA}, \mathrm{CIE} \mathrm{a}^{*}, \mathrm{CIE} \mathrm{a}^{*} / \mathrm{b}^{*}, \mathrm{SSC} / \mathrm{TA}$ 그리고 $\mathrm{SSC}$ 로 나타났으며 관능적 품질 특성은 과피의 두께로 나타났다. 본 실험 결과 이화학적 품질 특성인 경도, $\mathrm{CEE} \mathrm{L}^{*}$, 적정산도, $\mathrm{CIE} \mathrm{a} * / \mathrm{b}^{\star}, \mathrm{SSC} / \mathrm{TA}$, 그리고 $\mathrm{SSC}$ 와 관능적 품질 특성인 단 맛, 과립의 탄력도, 포도 향, 색의 정도, 신맛 등을 'Campbell early' 포도의 품질지표로 적용하였을 때 소비자 기호도 예측이 가능할 것으로 생각된다.

\section{감사의 글}

본 논문은 농림축산식품부의 재원으로 농림수산식품기 술기획평가원의 고부가가치식품기술개발사업의 지원을 받아 연구되었으며 이에 감사드립니다(과제번호:313029-3 '친환경농식품의 관능과 이화학적 품질지표 개발 및 계량 
화기술 개발).

\section{References}

1. Korea Rural Economic Institute http://aglook.krei.re.kr/ jsp/pc/front/observe/monthlyReport.jsp?ovr_item_code= OVR0000000007\&prt_ovr_item_code=OVR000000001 3 (accessed Dec 2015)

2. Hwang YS, Lim BS, Kim JG (2010) Comparison of 'Kyoho' and 'Campbell early' table grape fruit quality in wholesale market. J Agricultural science, 37, 7-12

3. Rural Development Administration http://www.nihhs.go. $\mathrm{kr} /$ farmer/research/yearly_view.asp?f_cd=\&curpage $=1 \& \mathrm{c}$ $\mathrm{cd}=$ ca 10415\&y_cd=\&d_no $=1309 \&$ totalSearchYn $=Y$ (accessed Dec 2015)

4. Chang MS, Cho SD, Kim DB, Kim GH (2009) Analysis of consumer preferences with regard to sensory quality attributes of Korean grapes. Korean J Food Preserv, 16, 204-210

5. Pages J, Tenenhaus M (2001) Multiple factor analysis combined with PLS path modeling. Application to the analysis of relationships between physicochemical variables, sensory profiles and hedonic judgements. Chemom Intell Lab Syst, 58, 261-273

6. Kim KP, Jung PC, Yang SR (2002) A hedonic price analysis of fruit products. Korea J Agri Economics, 43, 33-56

7. Hong SJ, Lee JW, Kim YC, Kim KY, Park SW (2003) Relationship between physicochemical quality attributes and sensory evaluation during ripening of tomato Fruits.

J Kor Soc Hort Sci, 44, 438-441

8. Park YM, Yoon TY, Hwang MG (2006) Analysis of storage method and shelf temperature effects in determining storage potential of 'Fuji' apples based on sensory evaluation. Kor J Hort Sci Technol, 24, 56-63

9. Ku KH, Lee KA, Choi JH (2015) Sensory properties of satsuma mandarin by quantitative descriptive analysis. Korean J Food Preserv, 22, 241-250

10. Cho SD, Chang MS, Kim DM, Kim GH (2010) Correlation between sensory quality and instrumental quality attributes in 'Campbell early' grape. Kor J Hort Sci Technol, 28, 691-695

11. Parpinello GP, Nunziatini G, Rombolà AD, Gottardi F, Versari A (2013) Relationship between sensory and NIR spectroscopy in consumer preference of table grape (cv Italia). Postharvest Biol Technol, 83, 47-53

12. Segade SR, Giacosa S, Torchio F, Palma LD, Novello V, Gerbi V, Rolle L (2013) Impact of different advanced ripening stages on berry texture properties of 'Red Globe' and 'Crimson Seedless' table grape cultivars (Vitis vinifera L.). Sci Hortic, 160, 313-319

13. Park SJ, Kim JG, Jung SM, Noh JH, Hur YY, Park KS (2011) Influence of leaf number on berry quality of 'Campbell early' grape. J Bio-Environ Control, 20, 211-215

14. Carreno J, Martinez A, Almela L, Fernandez-Lopez JA (1995) Proposal of an index for the objective evaluation of the colour of red table grapes. Food Res Int, 28, 373-377

15. Matsumoto K, Kim BK, Oahn VTK, Seo JH, Yoon HK, Park MK, Hwang YS, Chun JP (2007) Comparison of compositions and quality parameters during berry ripening between grape cultivars. Kor J Hort Sci Technol, $25,230-234$

16. Coombe BG, Dundon RJ, Short AWS (1980) Indices of sugar-acidity as ripeness criteria for winegrapes. J Sci Food Agric, 31, 495 - 502

17. Bisson L (2001) In search of optimal grape maturity. Practical Winery Vineyard J, Jul/Aug, 32-43

18. Park ER, Kim KS (2000) Volatile flavor components in various varieties of grape (Vitis vinifera L.). Korea J Postharvest Sci Technol, 7, 366-372

19. Moigne ML, Maury C, Bertrand D, Jourjon F (2008) Sensory and instrumental characterisation of Cabernet Franc grapes according to ripening stages and growing location. Food Qual Prefer, 19, 220-231

20. Maury C, Madieta E, Moigne ML, Mehinagic E, Siret R, Jourjon F (2009) Development of a mechanical texture test to evaluate the ripening process of Cabernet Franc grapes. J Texture Stud, 40, 511-535 